\title{
Perinatal Development of Myoinositol Uptake into Lung Cells: Surfactant Phosphatidylglycerol and Phosphatidylinositol Synthesis in the Rabbit
}

\author{
MIKKO HALLMAN, STEFAN SLIVKA, PAUL WOZNIAK, AND JACK SILLS
}

Children's Hospital, University of Helsinki, 00290 Helsinki, Finland, and Department of Pediatrics, School of Medicine, University of California, San Deigo, La Jolla, California 92093

\begin{abstract}
It has been proposed that the high serum myoinositol promotes fetal growth and affects development of lung surfactant. However, it is unclear how the extracellular myoinositol becomes available in specific cells and whether there are developmental differences in myoinositol uptake. In the present study the mechanisms and perinatai development of intracellular myoinositol uptake into rabbit lung cells were investigated. Lung slices, lung explants, and type II alveolar cells were used. Evidence of saturable, sodium- and energy-dependent, and of non-saturable, sodium- and energy-independent myoinositol uptake was found. The nonsaturable uptake decreased by $67 \%$ during spontaneous maturation, as studied in lung slices. Betamethasone $(0.2 \mathrm{mg} / \mathrm{kg}$ days 26.3 and 27.3 , to the doe $)$ decreased by $65 \%$ the nonsaturable myoinositol uptake in 28-day-old fetuses. However, the saturable uptake revealed only small changes during perinatal development. The effect of extracellular myoinositol on surfactant phospholipid synthesis was evaluated in lung explants from 28day-old fetuses, cultured for 2 days. In the presence of $10^{-6}$ $M$ dexamethasone the concentration of extracellular myoinositol, required for half-maximal inhibition of surfactant phosphatidylglycerol incorporation was higher than in explants grown without the hormone (approximately 0.4 versus $0.2 \mathrm{mM}$ ). However, in the microsomal fraction the phosphatidylglycerol incorporation was always inhibited by as low as $4 \mu \mathrm{M}$ myoinositol. Myoinositol was taken up by isolated type II cells preferably by nonsaturable mechanism. The phosphatidylglycerol incorporation was less sensitive to extracellular myoinositol in adult than in fetal cells. Although there were only small changes in the concentration of free myoinositol in whole lung during perinatal development, the availability of this sugar alcohol to some specific cells decreased strikingly due to a decrease in serum concentration and a decrease in permeability of this putative growth factor. The present findings demonstrate that some cells within myoinositol-rich tissue can be devoid of this sugar alcohol and critically depend on extracellular source for their myoinositol supply. (Pediatr Res 20: $179-185,1986$ )
\end{abstract}

\section{Abbreviations}

PG, phosphatidylglycerol

PI, phosphatidylinositol

MEM, minimal essential medium with Hanks' salts

Received June 12. 1985; accepted October 9, 1985

Address for correspondence Mikko Hallman, M.D., Children's Hospital, University of Helsinki, Stenbäckinkatu 11, SF-00290 Helsinki, Finland.

Supported by NIH Grant HD-04380 (to Dr. Louis Gluck), Finnish Academy, and Sigrid Jusélius Foundation (M.H.)
Myoinositol excess or deficiency is associated with diabetic and uremic neuropathy $(1,2)$, and with respiratory distress syndrome (3-6). However, it has been difficult to define whether an abnormal serum myoinositol is related to abnormal availability of this sugar in individual cells. Various organs have a characteristic, generally high content of myoinositol (7). This can be due to active intracellular uptake (8-12), intracellular binding (13), or synthesis of myoinositol from glucose 6-phosphate.

Myoinositol is incorporated into phosphoinositides, and in kidney it is also oxidized into glucuronic acid (14). Myoinositol pools within a number of tissues undergo a rapid turnover as a result of specific stimuli, for instance nerve impulse transmission, hormone secretion, or mitogenic stimulus (15). The enhanced myoinositol turnover, as an early postreceptor event involves hydrolysis of phosphoinositide (resulting in a change in membrane characteristics) and a subsequent incorporation into phosphoinositide. However, the concentration of myoinositol in individual cells may not be uniform (16) and a given myoinositol pool within the tissue may not be associated with postreceptor events involving enhanced turnover (17).

In type II alveolar cells $(6,18)$ and in some extrapulmonary cells (19) there is a reciprocal relationship between the synthesis of PI and PG, possibly because myoinositol stimulates PI synthesis, and thereby depletes the rate limiting substrate, CDPdiacylglycerol, required for PG (4). This concept implies that the availability of myoinositol in type II cells affects the concentration of individual acidic phospholipids. Indeed surfactant P1 and PG appear successively and serum levels of myoinositol decrease concomitant with perinatal lung maturation (20-22).

In the present investigation the relationship between extracellular myoinositol, pulmonary myoinositol uptake, and between myoinositol-sensitive phospholipid incorporation has been evaluated.

\section{MATERIALS AND METHODS}

New Zealand White rabbits were used. The animals received $30-45 \mathrm{mg} / \mathrm{kg}$ Ketamine $\mathrm{HCl}$ (Parke-Davis, Detroit, MI) and 10$15 \mathrm{mg} / \mathrm{kg}$ Xylazine (Haver-Lochart, Shawnee, KS). In addition, $0.25 \%$ lidocaine was used in local anesthesia. The fetuses were sacrificed by intracerebral thiopental sodium $(10 \mathrm{mg})$ through uterine wall, and subsequently bled through the abdominal aorta.

The isotopes were purchased from New England Nuclear (Boston, MA). CDP-diacylglycerol (egg lecithin derivative, from Serdary Research Laboratories, London, Ontario, Canada) was further purified as described previously (23).

Uptake of myoinositol into lung slices. Fresh lungs were chopped in Krebs-Ringer phosphate buffer, or when indicated, in Krebs-Ringer phosphate containing $\mathrm{Li}^{+}$instead of $\mathrm{Na}^{+}$. After removing the large airways, lung slices, $0.5 \mathrm{~mm}$ thick, were prepared using Stadie Riggs slicer (Arthur Thomas Co, Philadelphia, PA). The slices were dried on a filter paper, weighed, and 
trimmed to a weight range of 35 to $45 \mathrm{mg}$. A slice was transferred to $3 \mathrm{ml}$ of Krebs-Ringer phosphate medium containing $2 \%(\mathrm{w} /$

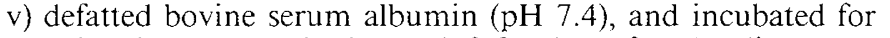
$15 \mathrm{~min}$ with gentle agitation at $37^{\circ} \mathrm{C}$. Thereafter the slices were dried and transferred to gas tight vials containing $1 \mathrm{ml}$ of KrebsRinger bicarbonate supplemented with $5 \mathrm{mM}$ glucose and $2 \%$ bovine serum albumin ( $\mathrm{pH} 7.4$ ), in $95 \% \mathrm{O}_{2}$ and $5 \% \mathrm{CO}_{2}$. The incubation medium additionally contained $\left[2-{ }^{3} \mathrm{H}\right]$ myoinositol (spec. act. 4 to $140 \mu \mathrm{Ci} / \mu \mathrm{mol}$ ) and $10 \mu \mathrm{M}\left[{ }^{14} \mathrm{C}\right]$ mannitol (spec. act. $40 \mu \mathrm{Ci} / \mu \mathrm{mol}$ ). The slices were incubated for $15 \mathrm{~min}$ at $37^{\circ}$ $\mathrm{C}$, unless otherwise indicated. The composition of the preincubation and incubation media, as well as the incubation time were often modified, as indicated in "Results." After the incubation, the slices were dried, weighed, transferred to Millipore filters, washed with Krebs-Ringer phosphate, and homogenized in icecold $0.5 \mathrm{M}$ perchloric acid. The homogenate was centrifuged at $5000 \times g$ for $10 \mathrm{~min}$. The supernatant was counted for radioactivity using the channel ratio method. The radioactive myoinositol, taken up to the intracellular space, was calculated as follows: Intracellular $\left[2-{ }^{3} \mathrm{H}\right]$ myoinositol $=\left[2-{ }^{3} \mathrm{H}\right]$ myoinositol in the lung $-\left[{ }^{14} \mathrm{C}\right]$ mannitol in the lung $\times$ total $\left[2-{ }^{3} \mathrm{H}\right]$ myoinositol/total $\left[{ }^{14} \mathrm{C}\right]$ mannitol.

During each experiment the intracellular water was measured as the difference between total lung water and extracellular water (=mannitol space). The total tissue water was the weight difference between the fresh and freeze dried lung. The mannitol space was obtained by incubating the lung slices, as described above, in the presence of $10 \mu \mathrm{M}\left[{ }^{14} \mathrm{C}\right] \mathrm{mannitol}$ for $30 \mathrm{~min}$. The $\left[{ }^{14} \mathrm{C}\right]-$ radioactivity taken up by the slices was used to calculate the mannitol space. In some experiments $\left[{ }^{3} \mathrm{H}\right]$ carboxyinulin was included in the incubation medium together with $\left[{ }^{14} \mathrm{C}\right] \mathrm{mannitol}$ The inulin and mannitol spaces were not significantly different.

Experiments with organ culture. The lungs were obtained from 28-day-old fetuses. The organ culture system was a modification of that described by Gross et al. (24) and others (3). The lungs were chopped into 0.3 to $0.8 \mathrm{~mm}^{3}$ cubes. Twenty (labeling experiments) or 40 (isolation of microsomes and mitochondria) explants were placed on a culture dish, diameter $35 \mathrm{~mm}$. The sterile culture medium, $0.6 \mathrm{ml}$ to each dish, contained the MEM (from K.C. Biological, Lenexa, KA), $100 \mathrm{U} / \mathrm{ml}$ penicillin and $100 \mu \mathrm{g} / \mathrm{ml}$ streptomycin. When indicated the culture medium additionally contained $10^{-6} \mathrm{M}$ dexamethasone and/or extra myoinositol. The explants were cultured at $37^{\circ} \mathrm{C}$ in a humidified atmosphere containing $20 \% \mathrm{O}_{2}$ and $5 \% \mathrm{CO}_{2}$. The culture chamber (Bellco Glass, Inc., Vineland, NJ) rotated at a rate of 9 cycles/ min (Rotating Platform, Heidolph, West Germany), allowing the explants to be cyclically exposed to the culture medium and to the atmosphere. After 3 days in culture a vast majority of the cells were well preserved and excluded the vital dye. Type II cells were predominant alveolar epithelial cells, as demonstrated by electron microscopy.

For studies of the incorporation of the label into phospholipids a new medium was added after $48 \mathrm{~h}$ in culture. This was identical to the previous medium except that it contained $0.25 \mathrm{mM}$ $\left[1-{ }^{14} \mathrm{C}\right]$ sodium acetate $(10 \mu \mathrm{Ci} / \mu \mathrm{mol})$, and when indicated extra myoinositol, as shown in "Results." After the incubation with the radioactive isotope for $16 \mathrm{~h}$, the medium was removed. Thereafter the explants were recovered and the lamellar body and the mitochondrial fractions were isolated as described previously (3). The radioactivity associated with saturated phosphatidylcholine $(25,26), \mathrm{PG}, \mathrm{PI}$, phosphatidylcholine, sphingomyelin, and phosphotidylethanolamine was analyzed as described earlier (23).

The microsomal and mitochondrial fraction were isolated as described previously (23). The wet weight of the starting material was $0.5-0.8 \mathrm{~g}$ (25-40 dishes). The recovery of the microsomes $(1.0 \pm 0.3 \mathrm{mg} / \mathrm{g}$ wet weight) and mitochondria $(1.2 \pm 0.4 \mathrm{mg} / \mathrm{g}$ wet weight) was similar in the hormone exposed and the control lungs. Succinate cytochrome $\mathrm{C}$ reductase and NADPH cyto- chrome $\mathrm{C}$ reductase activities were measured in mitochondria and microsomes (23). On the basis of these assays there was $12 \%$ mitochondrial protein contamination in the microsomal fraction and $12 \%$ microsomal contamination in the mitochondrial fraction.

The effect of myoinositol on $\left[{ }^{14} \mathrm{C}\right]$ glycerol $3-\mathrm{PO}_{4}$ incorporation into $\mathrm{PG}$ and phosphatidylglycerolphosphate was studied using mitochondria and microsomes (4). Forty microliters of the incubation mixture containing $30 \mu \mathrm{M}$ CDP-diacylglycerol, $6 \mathrm{mM}$ reduced glutathione, $5 \mathrm{mM} \mathrm{MnCl}{ }_{2}, 0.5 \mathrm{mM}$ glycerol 3- $\mathrm{PO}_{4}(52$ $\mu \mathrm{Ci} / \mu \mathrm{mol}$ ), $100 \mathrm{mM}$ Tris $-\mathrm{HCl}, 60 \mu \mathrm{g}$ protein (microsomes or mitochondria), myoinositol, and when indicated $2 \mathrm{mM}$ CMP. CDP-diacylglycerol was first added to the conical tube. The enzyme and $\mathrm{MnCl}_{2}$, in that order were added last, followed by mixing with a Vortex. The incubation took place for $15 \mathrm{~min}$ at $37^{\circ} \mathrm{C}$ with continuous agitation. After the incubation, the lipid radioactivity was measured (23).

Isolation and experiments with type II cells. Type II cells were isolated from the lungs of adult and 30-day-old fetal rabbits essentially according to Mason et al. (27) with several modifications. Young male rabbits (weighing) $1.0-1.2 \mathrm{~kg}$ received 4000 $U$ of sodium heparin intraperitoneally and were bled through the carotid artery. The pulmonary vessels were perfused through a catheter placed in the pulmonary artery, until the lungs appeared bloodless. The perfusion medium contained $135 \mathrm{mM}$ $\mathrm{NaCl}, 4 \mathrm{mM} \mathrm{KCl}, 2.0 \mathrm{mM}$ sodium phosphate, $10 \mathrm{mM}$ HEPES, $5 \mathrm{mM}$ glucose, $100 \mathrm{U} / \mathrm{ml}$ penicillin $100 \mu \mathrm{g} / \mathrm{ml}$ streptomycin, $\mathrm{pH}$ 7.4 (medium 1). The trachea was cannulated and the airways were lavaged five times by introducing and withdrawing about $15 \mathrm{ml} / \mathrm{kg}$ body wt of sterile isotonic saline, in order to remove macrophages. The fetuses received $200 \mathrm{U}$ heparin intraperitoneally. The lungs were perfused through a catheter in the pulmonary artery, distal to the ductus arteriosus.

Large airways were removed and the tissue was minced until the final size of the pieces was about $1 \mathrm{~mm}^{3}$. Any remaining blood and cell debris was removed by washing with $135 \mathrm{mM}$ $\mathrm{NaCl}, 4 \mathrm{mM} \mathrm{KCl}, 2.0 \mathrm{mM}$ sodium phosphate, $1.7 \mathrm{mM} \mathrm{CaCl}_{2} 1$ $\mathrm{mM} \mathrm{MgSO}_{4}, 10 \mathrm{mM}$ HEPES, $5 \mathrm{mM}$ glucose, $100 \mathrm{U} / \mathrm{ml}$ penicillin, $100 \mu \mathrm{g} / \mathrm{ml}$ streptomycin, pH 7.4 (medium II). Thereafter medium II, that contained $3 \mathrm{mg} / \mathrm{ml}$ of trypsin, $30 \mu \mathrm{g} / \mathrm{ml}$ DNA:se (Sigma), was added $(10 \mathrm{ml} / \mathrm{g}$ tissue). The dispersion was incubated for $35 \mathrm{~min}$ in a reciprocating water bath at 60 cycles/min at $37^{\circ} \mathrm{C}$. Thereafter $1.5 \mathrm{ml}$ of fetal calf serum/g of lung was

Table 1. Intracellular myoinositol uptake into the lung slices; sodium and energy dependence*

\begin{tabular}{|c|c|c|c|c|}
\hline \multirow{2}{*}{$\begin{array}{l}\text { Concentration of myoinositol } \\
\qquad \mathrm{Agc}\end{array}$} & \multicolumn{2}{|c|}{$10 \mu \mathrm{M}$} & \multicolumn{2}{|c|}{$2 \mathrm{mM}$} \\
\hline & $\begin{array}{l}28-d a y \\
\text { fetus }\end{array}$ & Adult & $\begin{array}{l}28 \text {-day } \\
\text { fetus }\end{array}$ & Adult \\
\hline $\begin{array}{l}\text { Alteration in standard incuba- } \\
\text { tion medium: }\end{array}$ & \multicolumn{4}{|c|}{$\mathrm{nmol} \cdot \mathrm{h}^{-1} \cdot \mathrm{g}$ of tissue ${ }^{-1}$} \\
\hline Vone & 6.9 & 5.9 & 106 & 68 \\
\hline $\mathrm{Li}^{+}$, instead of $\mathrm{Na}^{+}$ & 2.0 & 2.0 & 74 & 40 \\
\hline $2 \mathrm{mM}$ ouabain & 2.2 & 1.9 & 76 & 40 \\
\hline $\mathrm{Li}^{+}$and ouabain & 0.5 & 0.3 & 56 & 28 \\
\hline $\begin{array}{l}1 \mathrm{mM} \text { potassium cyanate }+ \\
1 \mathrm{mM} \text { 2-deoxyglucose }\end{array}$ & 1.4 & 1.1 & 50 & 27 \\
\hline
\end{tabular}

* Uptake of $\left[2-{ }^{3} \mathrm{H}\right]$ myoinositol into rabbit lung slices was measured as described in "Methods." The uptake was expressed as $\mathrm{nmol} / \mathrm{h}$ per gram of the fresh weight of the tissue. For the preincubation period without the isotope in Krebs-Ringer phosphate buffer $+2 \%$ bovine serum albu$\min (15 \mathrm{~min})$ and the incubation period in Krebs-Ringer bicarbonate supplemented with $5 \% \mathrm{mM}$ glucose. $2 \%$ albumin, and myoinositol (15 min), the medium was modified further as detailed above. The measurements of the myoinositol uptake were performed in triplicate and repeated in two occasions. The SE of the triplicate measurements was $<15 \%$. 
added to inhibit the trypsin activity. The cell suspension was filtered through $150 \mu \mathrm{m}$, and $20 \mu \mathrm{m}$ nylon mesh (Tobler, Ernst and Traber, Inc., Elmsford, NY). The filtrate was layered on the top of a discontinous gradient containing $10 \mathrm{ml}$ of albumin (Path-O-cyte 4, Miles Laboratories, Kankake, IL), density 1.088, and $10 \mathrm{ml}$ of albumin, density 1.040 . After centrifugation at 200 $\times \mathrm{g}$ for $20 \mathrm{~min}$ the $1.040-1.080$ interphase was recovered. Thereafter the type II cells were further purified by differential adherence in primary culture according to Dobbs and Mason (28). The culture medium contained MEM, $100 \mathrm{U}$ penicillin/ $\mathrm{ml}, 100 \mu \mathrm{g}$ streptomycin $/ \mathrm{ml}$, and $10 \%(\mathrm{v} / \mathrm{v})$ serum from adult rabbit. More than $90 \%$ of the cells that adhered to the culture dish during $20 \mathrm{~h}$ excluded the vital dye, erythrocin B (29). Electron microscopy revealed that $75-85 \%$ of the cells were type II alveolar cells.

In order to study myoinositol uptake, the cells that were adherent to the dish during $20 \mathrm{~h}$ in culture, were detached from the surface of the flask by rubber policeman. Together $2-3 \times 10^{6}$ cells were suspended to $1 \mathrm{ml}$ of serum-free MEM, that contained $\left[2-{ }^{3} \mathrm{H}\right]$ myoinositol and $10 \mu \mathrm{M}\left[{ }^{14} \mathrm{C}\right]$ mannitol. The suspension was incubated with gentle agitation for $15 \mathrm{~min}$ at $37^{\circ} \mathrm{C}$ in $95 \%$ $\mathrm{O}_{2}-5 \% \mathrm{CO}_{2}$ atmosphere. After the incubation the suspension was washed on millipore filters $(0.22 \mu \mathrm{m})$, and the radioactivity associated with the filter was counted. The intracellular myoinositol uptake was calculated as the amount of $\left[{ }^{3} \mathrm{H}\right]$ myoinositol minus the amount of $\left[{ }^{14} \mathrm{C}\right]$ mannitol that was present in the filter (see "Methods": myoinositol uptake).

The incorporation of $\left[{ }^{14} \mathrm{C}\right]$ acetate into phospholipids of type II cells was studied as follows. After the differential adherence the type II cells were further cultured in MEM containing 0.5 $\mathrm{mM}\left[1-{ }^{14} \mathrm{C}\right]$ sodium acetate and a known amount of myoinositol for $20 \mathrm{~h}$. Thereafter, the medium was removed and the cells were detached using a rubber policeman. Subsequently the phospholipid-associated radioactivity was analyzed in the media and the cells.

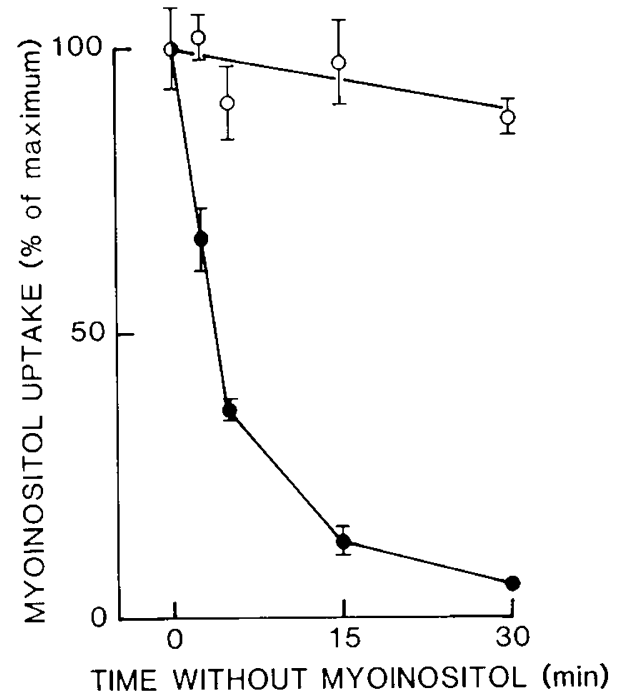

Fig. 1. The reversibility of $\left[2-{ }^{3} \mathrm{H}\right]$ myoinositol uptake. The experiment took place in two different conditions. Open circles, the slices were incubated for $15 \mathrm{~min}$ in the presence of $10 \mu \mathrm{M}\left[2-{ }^{3} \mathrm{H}\right]$ myoinositol and $10 \mu \mathrm{M}\left[{ }^{14} \mathrm{C}\right]$ mannitol as described in "Methods." Thereafter the slices were dried and transferred to a new medium that was identical to the previous one except that it contained neither myoinositol nor mannitol. The incubation time in the new medium is shown. The intracellular $\left[{ }^{3} \mathrm{H}\right]$ radioactivity is expressed as percentage of the control (zero time). Closed circles, the experiment was similar to the previous one except that the first incubation was in the presence of $2 \mathrm{mM}\left[2-{ }^{3} \mathrm{H}\right]$ myoinositol, $10 \mu \mathrm{M}$ $\left[{ }^{14} \mathrm{C}\right]$ mannitol. Furthermore. the first and the second incubation media contained $\mathrm{Li}^{+}$. instead of $\mathrm{Na}^{+}$. and $2 \mathrm{mM}$ ouabain. The results are expressed as means $\pm \mathrm{SE}$ of four experiments.

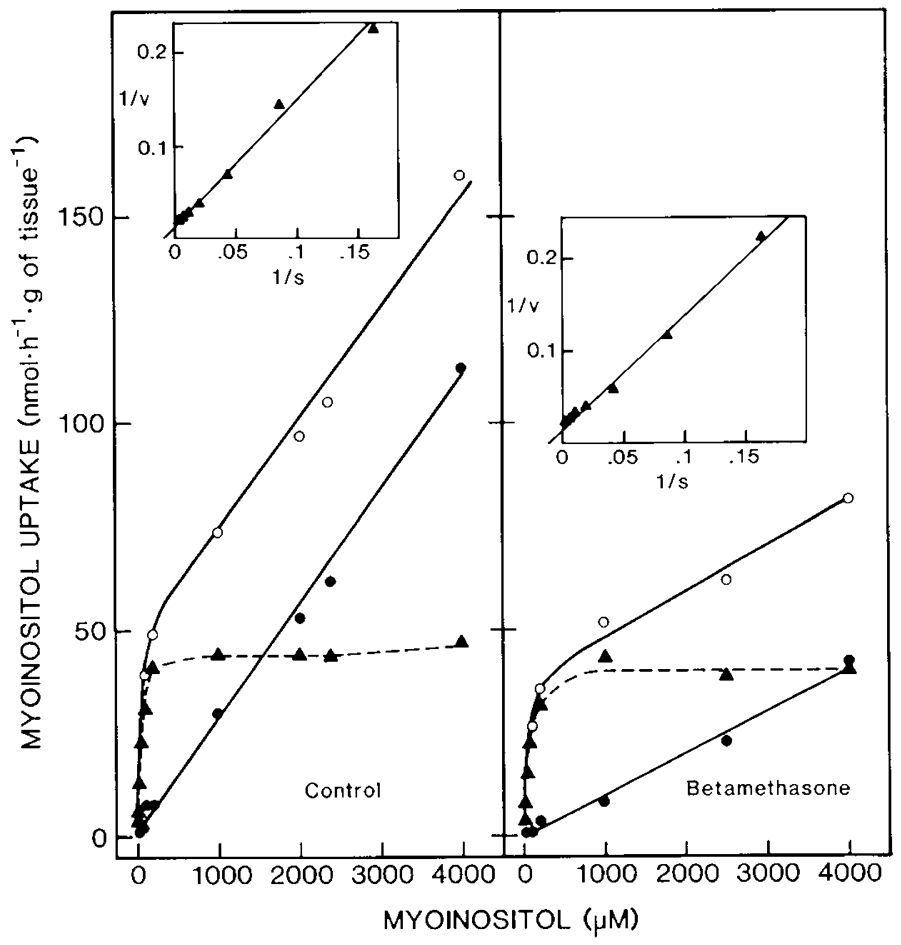

Fig. 2. Intracellular myoinositol uptake as a function of medium myoinositol concentration. The lung slices were incubated in the presence of varying concentrations $\left[2-{ }^{3} \mathrm{H}\right]$ myoinositol and $10 \mu \mathrm{m}\left[{ }^{14} \mathrm{C}\right]$ mannitol for $15 \mathrm{~min}$. Intracellular myoinositol uptake was calculated on the basis of total tissue $\left[{ }^{3} \mathrm{H}\right]$ myoinositol minus the amount of $\left[{ }^{3} \mathrm{H}\right]$ myoinositol present in extracellular (mannitol) space. Open circles, uptake in the presence of $\mathrm{Na}^{+}$. Closed circles, uptake in the presence of $\mathrm{Li}^{+}$, instead of $\mathrm{Na}^{+}$, and $2 \mathrm{mM}$ ouabain. Dashed line with triangles, sodium-dependent uptake; i.e. uptake in the presence of $\mathrm{Na}^{+}$minus uptake in the presence of $\mathrm{Li}^{+}$and ouabain. The inset shows sodium-dependent uptake plotted in double reciprocal fashion (Lineweaver-Burk transformation). Each point represents the mean of three experiments. Left, slices from 28 -day old fetus. Right, 28-day old fetus, betamethasone treatment $(0.2 \mathrm{mg} / \mathrm{kg}$ days, 26.3 and 27.3 to the doe). The measurements were done in triplicate and repeated in two occasions. The SE of the triplicate measurements was $<15 \%$.

Other methods. Myoinositol was measured as the trimethylsilyl derivative using gas liquid chromatography as described previously (21). The results were expressed as means \pm SE. The statistical significance was calculated using the two-tailed $t$ test.

\section{RESULTS}

Myoinositol uptake into the lung slices. Neither the age nor the glucocorticoid treatment significantly affected the intracellular water, expressed as percentage of the fresh weight of the lung. Therefore, the myoinositol uptake was expressed on the basis of the fresh weight of the tissue.

In preliminary studies the lung slices were obtained from 28 day-old fetuses and from adults. The myoinositol uptake was linear during $30 \mathrm{~min}$ of incubation in the presence of $10 \mu \mathrm{M}$ myoinositol. Ouabain, $\mathrm{Li}^{+}$(instead of $\mathrm{Na}^{+}$), and sodium cyanide decreased myoinositol uptake (Table 1). The percentage inhibition was always higher in the presence of $10 \mu \mathrm{M}$, instead of 2 $\mathrm{mM}$ myoinositol. The effects of $\mathrm{Li}^{+}$and ouabain (increased intracellular $\mathrm{Na}^{+}$) were additive. Therefore, in subsequent experiments sodium independent myoinositol uptake was studied in the presence of both $\mathrm{Li}^{+}$and ouabain.

The myoinositol taken up by the lung was analyzed. Regardless of the source of the lung or the presence of myoinositol transport 
inhibitors less than $5 \%$ of the label was associated with lipids and more than $90 \%$ of the lipid radioactivity was recovered in phosphomonoinositide fatetion. The nonlipid radioactivity was analyzed for carbohydrates as described previously (3). All [ $\left.{ }^{3} \mathrm{H}\right]-$ radioactivity was associated with the nonphosphorylated myoinositol

Reversibility of the intracellulat myoinositol-uptake. Fïgure 1 shows the disappearance of the intracellular myoinositol taken up by the lung in vitro. I.ess than $20 \%$ of myoinositol taken up by nonsaturable concentration-dependent mechanism was lost during subsecpuent incubation for $20 \mathrm{~min}$ in myoinositol-fiec medium. However, more than $90 \%$ of the intracellular myoinositol that was taken up by the sodium-independent mechanism disappeared from the tissue.

Development of myeinositol uphoke. The uptake was measured at myoinositol concentrations ranging from $4 \mu \mathrm{M}$ to $4 \mathrm{mM}$, in order to detect a saturable transport component. Figure 2 shows the concentration-dependence of the uplake into lung slices from 28-day-old rabbit fetuses (controls and glucocorticoid treated). The uptake increased linearly with medium myoinositol from 6 to $25 \mu \mathrm{M}$. Thereafter, partial saturation occurred between 25 and $200 \mu \mathrm{M}$. At higher myoinositol concentrations the uptake increased linearly with the medium myoinositol concentration to the highest level tested $(4.0 \mathrm{mM})$. This suggests that the uptake consists of at least two transport components.

The intracellular myoinositol uptake in the absence of $\mathrm{Na}$ was directly proportional to medium myoinositol concentration. The slope of the increase in intracellular myoinositol uptake was higher in the control lung than after the glucocorticoid treatment.

When the sodium-dependent intracellular uptake and the extracellular myoinositol concentration were plotted as their double reciprocals (Lineweaver-Burk transformation, Fig. 2, inset) a linear relationship was generated. This allowed the calculation of apparent concentration required for half-maximal transport and of the maximal rate of transport. The glucocorticoid treatment had no detectable effect on either half maximal transport or maximal rate of transport.

Table 2 shows the apparent half maximal transport and maximal rate of transport of the sodium-dependent uptake; rate of the sodium independent uptake; PG/PI ratio in alveolar lavage; and the concentrations of myoinositol in serum and in the lung. The sodium independent myoinositol uptake and serum myoinositol decreased during development. There was a negative linear correlation both between sodium-independent myoinositol uptake and PG/PI ratio $(r=0.66)$ and between serum

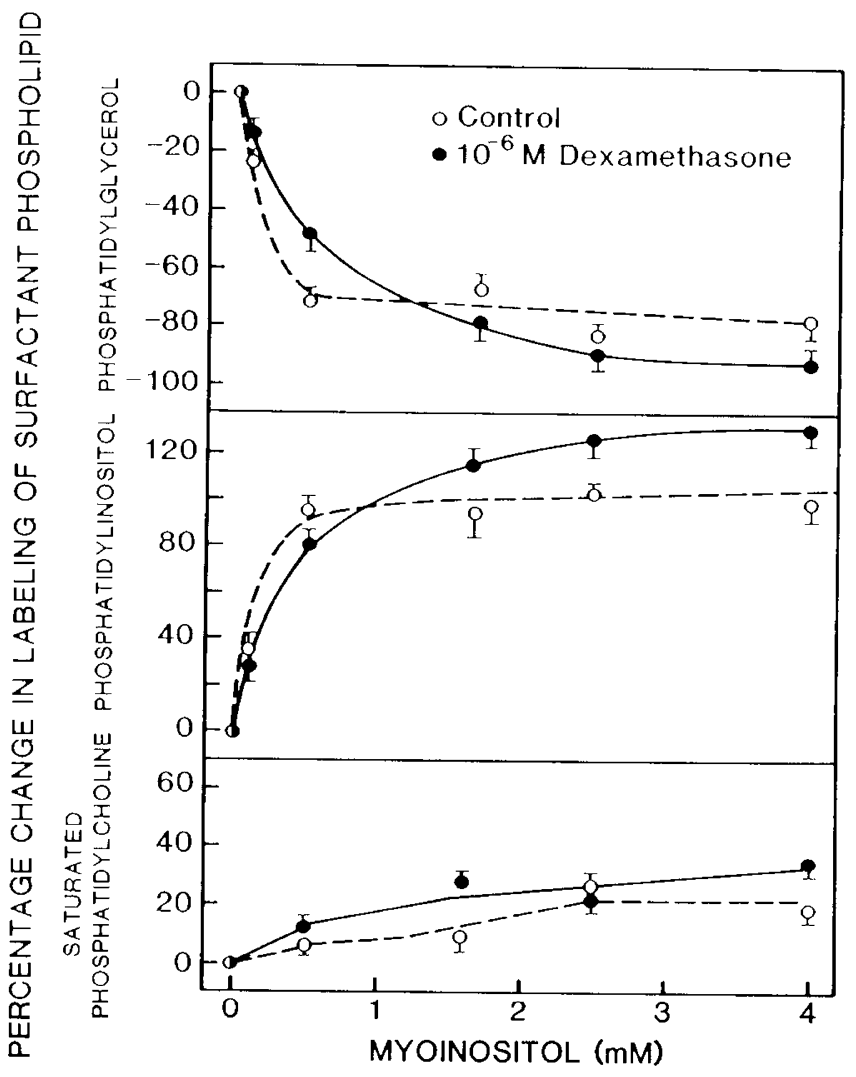

Fig. 3. Incorporation of $\left[{ }^{14} \mathrm{C}\right]$ acetate into the surfactant phospholipids in lung explants. The lung explants, obtained from 28-day-old rabbit fetuses, were cultured for two days in MEM $(O)$ or in MEM containing $10^{-6} \mathrm{M}$ dexamethasone $(\bullet)$. Thereafter the explants were cultured for additional $16 \mathrm{~h}$ in a new medium containing myoinositol (shown in $\mathrm{X}$ axis) and $0.25 \mathrm{mM}\left[1-{ }^{14} \mathrm{C}\right]$ sodium acetate $(10 \mu \mathrm{Ci} / \mu \mathrm{mol})$. The phospholipid radioactivities in the lamellar body fraction were expressed as percentage of the control activities without extra myoinositol (the activities in the presence of dexamethasone in parentheses): $970 \pm 80 \mathrm{cpm}$ $\mathrm{PG} / \mathrm{mg}$ whole lung prot.; $(1390 \pm 110 \mathrm{cpm} \mathrm{PG} / \mathrm{mg}$ prot. $) ; 1100 \pm 110$ $\mathrm{cpm} \mathrm{PI} / \mathrm{mg}$ prot. (1250 $\pm 120 \mathrm{cpm} \mathrm{PI} / \mathrm{mg}$ prot.); $22560 \pm 2170 \mathrm{cpm}$ saturated phosphatidylcholine/mg prot. $(24970 \pm 1730 \mathrm{cpm}$ saturated phosphatidylcholine/mg prot.).

Table 2. Perinatal development of myoinositol uptake into the lung, concentrations of myoinositol in serum and lung, and phosphatidylglycerol/phosphatidylinositol ratio in alveolar lavage*

\begin{tabular}{|c|c|c|c|c|c|c|}
\hline \multirow[b]{2}{*}{ Age } & \multicolumn{2}{|c|}{$\begin{array}{c}\text { Saturable, sodium- } \\
\text { dependent myoinositol } \\
\text { uptake }\end{array}$} & \multirow{2}{*}{$\begin{array}{l}\text { Non saturable, sodium } \\
\text { independent myoinositol } \\
\text { uptake in the presence } \\
\text { of } 2 \mathrm{mM} \text { myoinositol } \\
(\mathrm{nmol} / \mathrm{h} / \mathrm{g} \text { wet } \mathrm{wt})\end{array}$} & \multicolumn{2}{|c|}{$\begin{array}{l}\text { Myoinositol } \\
\text { concentration }\end{array}$} & \multirow[b]{2}{*}{$\begin{array}{l}\text { PG/PI ratio in } \\
\text { alveolar lavage }\end{array}$} \\
\hline & $\begin{array}{c}\mathrm{V}_{\max } \\
(\mathrm{nmol} / \mathrm{h} / \mathrm{g} \\
\text { wet wt) }\end{array}$ & $\begin{array}{c}\mathrm{K}_{\mathrm{m}} \\
(\mu \mathrm{M})\end{array}$ & & $\begin{array}{c}\text { Serum } \\
(\mu \mathrm{M})\end{array}$ & $\begin{array}{c}\text { Lung } \\
(\mu \mathrm{mol} / \mathrm{g} \\
\text { wet wt })\end{array}$ & \\
\hline \multicolumn{7}{|l|}{ Fetus } \\
\hline 26 days & 48 & 75 & 70 & $745 \pm 40$ & $3.7 \pm 0.5$ & $0.00 \pm 0.00$ \\
\hline 28 days & 53 & 75 & 56 & $678 \pm 81$ & $4.6 \pm 0.6$ & $0.01 \pm 0.00$ \\
\hline 31 days & 56 & 89 & 38 & $333 \pm 29$ & $3.9 \pm 0.2$ & $0.09 \pm 0.01$ \\
\hline \multicolumn{7}{|l|}{ Newborn } \\
\hline 2 days & 48 & 70 & 24 & $307 \pm 17$ & $4.2 \pm 0.4$ & $0.45 \pm 0.03$ \\
\hline Adult & 42 & 68 & 25 & $74 \pm 8$ & $3.6 \pm 0.3$ & $1.04 \pm 0.07$ \\
\hline
\end{tabular}

* The uptake of $\left[{ }^{2}-3 \mathrm{H}\right]$ myoinositol into the lung slices was measured as described in "Methods." The saturable, sodium-dependent myoinositol uptake was the intracellular uptake in standard conditions minus sodium-independent uptake (presence of $2 \mathrm{mM}$ ouabain and $\mathrm{Li}^{+}$, instead of $\mathrm{Na}^{+}$). The measurements of myoinositol uptake were performed in triplicate and repeated in two occasions. The coefficient of variation was $<15 \%$. The myoinositol concentrations and PG/PI ratios were the means \pm SE of 4-10 measurements. $V_{\max }$, maximal rate of transport; $K_{m}$, half maximal transport. 
myoinositol and PG/PI ratio $(r=0.84)$. The other parameters revealed little change.

Influence of the myoinositol on the phospholipid synthesis. Since glucocorticoid increases surfactant PG $(30,31)$ and the synthesis of this phospholipid is sensitive to myoinositol, we studied whether the hormone exposure of the fetal lung alters the myoinositol sensitivity of $\left[{ }^{14} \mathrm{C}\right]$ acetate incorporation into $\mathrm{PG}$.

Figure 3 shows the effect of extracellular myoinositol on incorporation of acetate into surfactant PG, PI, and saturated phosphatidylcholine fetal lung explants in vitro. Dexamethasone increased the extracellular concentration of myoinositol that was required to inhibit PG and stimulate PI incorporation. However, the hormone treatment did not decrease the maximal inhibitory effect of myoinositol.

In order to evaluate whether the observed difference in myoinositol sensitivity of $\left[{ }^{14} \mathrm{C}\right]$ acetate incorporation into $\mathrm{PG}$ is due to a difference in intracellular myoinositol uptake, the PG incorporation was studied in the microsomal preparation obtained from lung explants. There was little $\left[{ }^{14} \mathrm{C}\right]$ acetate incorporation into $\mathrm{PG}$ in the absence of CDP-diacylglycerol $(2 \mathrm{pmol}$. $\min ^{-1} \mathrm{mg}^{-1}$ prot.), even if $2 \mathrm{mM} \mathrm{CMP}$ was added to the mixture (6 pmol $\cdot \mathrm{min}^{-1} \mathrm{mg}^{-1}$ prot.). Addition of $0.4 \mathrm{mM} \mathrm{CDP}$-diacylglycerol activated $\left[{ }^{14} \mathrm{C}\right.$ ]acetate incorporation $\left(224 \mathrm{pmol} \cdot \mathrm{min}^{-1}\right.$,

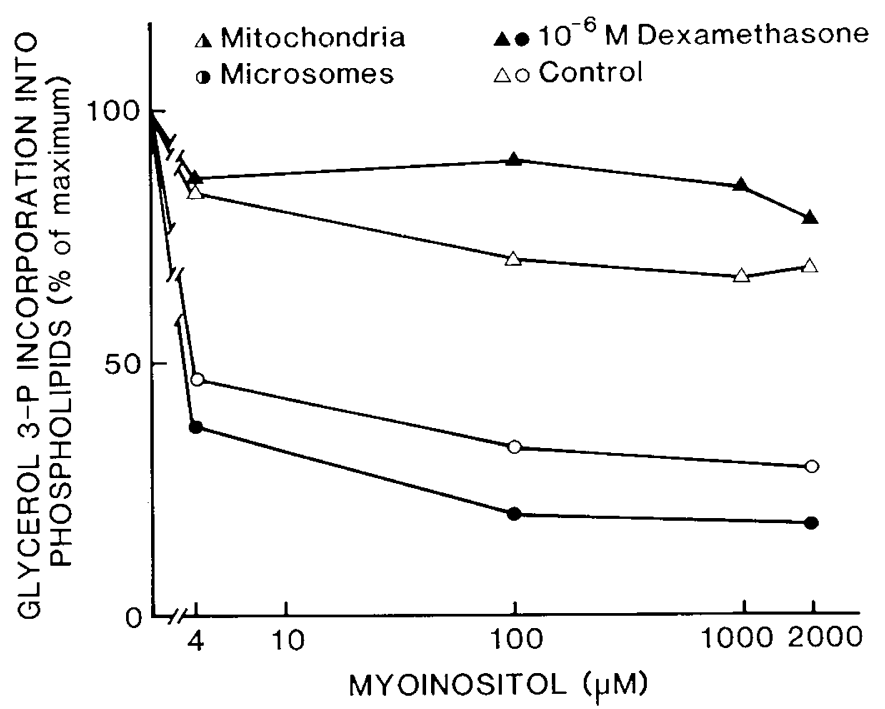

Fig. 4. Effect of myoinositol on the incorporation of $\left[{ }^{14} \mathrm{C}\right]$ glycerol 3$\mathrm{P}$ into $\mathrm{PG}+$ phosphatidylglycerolphosphate in subcellular organelles from lung explants. Mitochondria and microsomes $(1.5 \mathrm{mg}$ prot. $/ \mathrm{ml})$ were incubated in the presence of $30 \mu \mathrm{M}$ CDP-diacylglycerol and $0.5 \mathrm{mM}$ $\left[{ }^{14} \mathrm{C}\right]$ glycerol 3-P (4). The measurements were performed in duplicate and repeated in two occasions. The subcellular organelles were isolated from lung explants. The explants were obtained from 28-day-old rabbit fetuses and were cultured for 2 days in $\operatorname{MEM}(\Delta O)$ or in MEM containing $10^{-6} \mathrm{M}$ dexamethasone $(\boldsymbol{\Delta} \bullet)$. $\mathrm{mg}^{-1}$ prot.). In the presence of the CDP-diacylglycerol excess, neither $2 \mathrm{mM}$ myoinositol $\left(201 \mathrm{pmol} \cdot \mathrm{min}^{-1} \cdot \mathrm{mg}^{-1}\right.$ prot $)$ nor 2 $\mathrm{mM}$ CMP (219 $\mathrm{pmol} \cdot \mathrm{min}^{-1} \cdot \mathrm{mg}^{-1}$ prot.) had a large effect on $\left[{ }^{14} \mathrm{C}\right]$ acetate incorporation into $\mathrm{PG}$.

Decrease in CDP-diacylglycerol concentration rendered the microsomal PG incorporation sensitive to myoinositol. Figure 4 shows the rate of $\left[{ }^{14} \mathrm{C}\right]$ glycerol $3-\mathrm{P}$ incorporation into $\mathrm{PG}+$ phosphatidylglycerolphosphate as a function of myoinositol concentration. The microsomal PG incorporation was sensitive to myoinositol. In mitochondria the small effect of myoinositol on PG could in part be due to microsomal contamination. Under these conditions neither $2 \mathrm{mM}$ CMP, nor glucocorticoid had detectable effect on $\mathrm{PG}$ incorporation.

Experiments with isolated type II cells. A number of different cells rather than one cell type can contribute to the results. Therefore, myoinositol uptake in type II alveolar cells was further studied (Fig. 5). Cells isolated from term fetuses and young rabbits were used. The nonsaturable uptake was more prominent in type II cells than in the whole lung. The rate of myoinositol uptake was apparently higher in fetus than in the adult.

Table 3 shows the effect of extracellular myoinositol on the distribution of PG and PI synthesis in isolated type II cells. In type II cells from both fetuses and adults myoinositol tended to increase PI and decrease PG. In fetal cells these changes tended

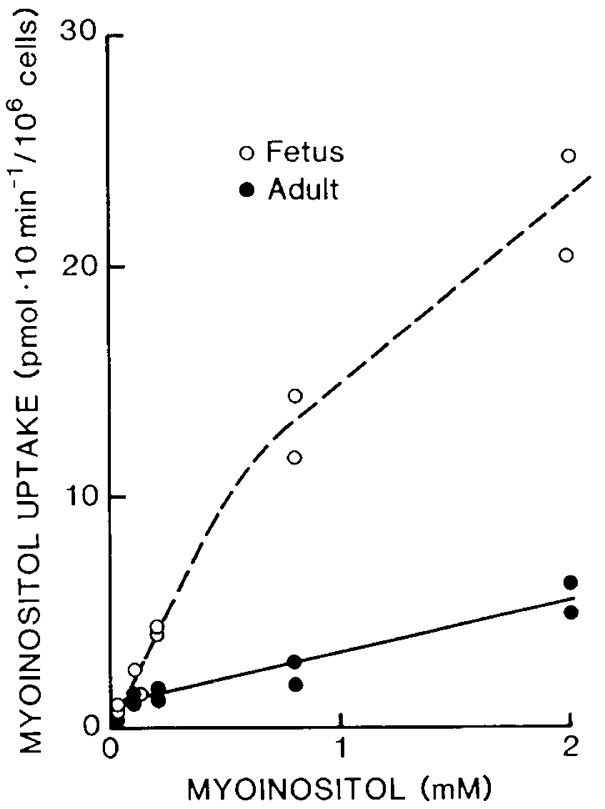

Fig. 5. Myoinositol uptake into type II cells from 31-day-old fetal and adult lung. The suspension, containing $1.5-2 \times 10^{6}$ cells in $0.5 \mathrm{ml}$ serum-free MEM was incubated for $15 \mathrm{~min}$ in the presence of $\left[2-{ }^{3} \mathrm{H}\right]$ myoinositol shown in $\mathrm{x}$ axis and $10 \mu \mathrm{M}\left[{ }^{14} \mathrm{C}\right]$ mannitol. The measurements were performed in duplicate and repeated in two occasions. For experimental details see "Methods."

Table 3. The effect of myoinositol on the incorporation of $\left[{ }^{14}\right.$ C]acetate into phosphatidylglycerol and phosphatidylinositol by intact type II cells*

\begin{tabular}{|c|c|c|c|c|}
\hline \multirow{2}{*}{$\begin{array}{c}\text { Concentration of } \\
\text { myoinositol } \\
(\mathrm{mM})\end{array}$} & \multicolumn{2}{|c|}{ Fetus, 30 days } & \multicolumn{2}{|c|}{ Adult } \\
\hline & $\%\left[{ }^{14} \mathrm{C}\right]$ in $\mathrm{PG}$ & $\%\left[{ }^{14} \mathrm{C}\right]$ in $\mathrm{PI}$ & $\%\left[{ }^{14} \mathrm{C}\right]$ in $\mathrm{PG}$ & $\%\left[{ }^{14} \mathrm{C}\right]$ in $\mathrm{PI}$ \\
\hline 0.01 & 9.9 & 5.5 & 11.4 & 4.0 \\
\hline 0.5 & 2.9 & 12.6 & 9.5 & 6.3 \\
\hline 2.0 & 1.1 & 12.9 & 3.0 & 12.0 \\
\hline
\end{tabular}

* Type II cells were cultured in MEM containing $0.5 \mathrm{mM}\left[1-{ }^{14} \mathrm{C}\right]$ acetate and various concentrations of myoinositol for $20 \mathrm{~h}$. The lipids in the cells and in the incubation media were analyzed for phospholipid radioactivity. The results are expressed as $\%$ of $\left[{ }^{14} \mathrm{C}\right]$ incorporation into total phospholipids and they are the means derived from two duplicate measurements in two experiments. 
to take place at lower myoinositol concentration than in the adult.

\section{DISCUSSION}

In the present study we have found evidence on two mechanisms of myoinositol uptake into lung cells, namely a undirectional, sodium- and energy-dependent transport and a nonsaturable, sodium- and energy-independent uptake. The present data on the energy-dependent uptake essentially confirm the earlier findings in the lung (8) and in other tissues $(9-12,32)$.

The concentration that allowed half-maximal energy-dependent uptake was 75-90 $\mu \mathrm{M}$, i.e. similar to adult serum myoinositol and clearly less than that in the fetus. Assuming that the properties of the transport system in vitro correspond to those in vivo, the uptake is active even with relatively low serum concentration and is saturated at higher myoinositol concentrations. On the other hand, the nonsaturable, energy-dependent uptake is always directly proportional to the extracellular myoinositol concentration.

A study on myoinositol content of individual brain cells in vivo revealed that the exceptionally high myoinositol, present in central nervous system, was not a feature of all cells (16). A similar phenomenon could occur in other organs, especially in the lung with its more than 40 different cells. It is possible that the differences in the intracellular myoinositol content are in part due to differences in intracellular uptake.

Our second aim was to correlate the extracellular myoinositol concentration with intracellular phospholipid synthesis. We have demonstrated a myoinositol-induced inhibition in PG synthesis and a corresponding increase in PI synthesis in a subcellular preparation mainly representing endoplasmic reticulum membranes. An analogous phenomenon has been demonstrated in intact lung (4) and in isolated type II cells $(6,18)$. In the cell-free system the concentrations required for maximal inhibition of PG were at least one order of magnitude lower than those required to suppress $P G$ in intact lung cells. It may be argued that the phenomenon taking place in cell-free preparation is essentially different from that in intact lung cells. However, the microsomal fraction that exhibited the myoinositol-sensitive PG synthesis has been pulse labeled in vivo. Its $\mathrm{PG}$ incorporation was also sensitive to myoinositol although the serum concentrations required for the inhibition were more than one order of magnitude higher than those in vitro. Furthermore, the in vivo labeled microsomes revealed a precursor-product relationship with the intracellular surfactant (26). This suggests that the myoinositol-induced suppression of PG in cell-free preparation represents the same phenomenon that takes place in intact cell, although the concentrations required are different owing to differences in availability of this sugar alcohol.

It has been proposed that the saturable, energy-dependent myoinositol uptake is in part responsible for increasing its concentration at the site of the acidic surfactant phospholipid synthesis (8). The maximal PG suppression was demonstrated first with extracellular myoinositol concentration that exceeded the maximum rate of the energy-dependent uptake. Furthermore, the myoinositol uptake into type II cells was predominantly nonsaturable (Fig. 5). Therefore, the availability of myoinositol into the site of the acidic surfactant phospholipid synthesis may depend on the nonsaturable uptake of myoinositol.

The third aim of the present study was to find out whether the intracellular myoinositol uptake changes in activity during perinatal development. This alteration is possible, since according to current hypothesis the concentration of myoinositol in type II cells decreases during maturation. There were no remarkable developmental trends in the saturable, energy-dependent uptake. However, both during spontaneous, and glucocorticoid-stimulated maturation there was a decrease in the nonsaturable uptake. This could be due to a decrease in the size of myoinositolaccessible intracellular space, due to increase in intracellular myoinositol concentration, or due to decrease in permeability. The last alternative is more likely because: 1) the nonsaturable uptake decreased both in the whole lung and in type II cells; 2) mature lung cells or glucocorticoid-exposed fetal lung explants required a higher concentration of extracellular myoinositol for suppression of $\mathrm{PG}$ synthesis than the fetal lung cells or lung explants. This difference cannot be due to an age-related change in extracellular permeability, since the intracellular myoinositol uptake was corrected for the extracellular sugar uptake using $\left[{ }^{14} \mathrm{C}\right]$ mannitol or $\left[{ }^{3} \mathrm{H}\right]$ carboxyinulin as a reference. Despite this there were no detectable differences in myoinositol suppressibility of PG synthesis in a subcellular preparation of the lung. This supports the concept that during perinatal development the type II alveolar cells (or at least the site of surfactant phospholipid synthesis) become less permeable to myoinositol.

We propose that there is a striking decrease in the availability of myoinositol to specific lung cells during perinatal development. This is due to a decrease in the extracellular concentration and a decrease in the permability of myoinositol. These additive phenomena are in part responsible for decrease in surfactant PI and increase in $\mathrm{PG}$.

Among the other mechanisms that possibly explain the increase in PG $(3,23)$, it has been proposed that CMP shifts the equilibrium of CDP-diacylglycerol:inositol phosphatidyltransferase toward CDP-diacylglycerol (33). This attractive hypothesis is supported by the observation that CMP content increases in developing lung possibly due to increase in surfactant phosphatidylcholine synthesis (34). However, Batenburg et al. (6) were unable to demonstrate that a stimulated phosphatidylcholine synthesis changes the distribution between PG and PI. This may be due to myoinositol or CDP-diacylglycerol that mask the effect of CMP on synthesis of the acidic surfactant phospholipids. Under the present experimental conditions myoinositol had little effect on surfactant phosphatidylcholine synthesis (Fig. 3), whereas there were differences in myoinositol uptake (Fig. 2, Table 2). Therefore the observed differences in the myoinositol sensitivity of PG synthesis (Fig. 3, Table 3 ) were not only due to differences in intracellular CMP.

The hypothesis that myoinositol is a vitamin-like essential nutrient (35) has been disputed on the basis of the fact that in any tissue there is active synthesis $(8,20,36)$ and generally high (although strictly tissue specific) intracellular concentration of this sugar alcohol (7). However, the present findings demonstrate why some cells within myoinositol-rich tissue may have a low concentration of this sugar alcohol and depend on extracellular source for their myoinositol supply.

Conditions may exist that are associated with increased or decreased extracellular myoinositol concentration. For instance, high serum levels may promote fetal growth and differentiation $(3,35)$. Maintenance of rodents on myoinositol-free diet results in intestinal lipodystrophy (37) or fatty liver (38). On the other hand, this sugar alcohol increases the growth of some malignant cells in vitro (39). Therefore, the causes and consequences of myoinositol "excess" and "deficiency" remain to be further elucidated.

Acknowledgments. The authors thank Mrs. Ellen Riihelä and Helena Ahola for excellent technical assistance and Mrs. Arja Lehtonen for typing the manuscript.

\section{REFERENCES}

1. De Jesus PV Jr, Clements RS Jr, Winegard AJ 1974 Hypermyoinositolemic polyncuropathy in rats: a possible mechanism for uremic neuropathy. Neurol Sci 21:237-249

2. Greene DA, De Jesus PV Jr. Winegrad AI 1975 Effects of insulin and dietary myoinositol on impaired peripheral motor nerve conduction velocity in acute streptozotocin diabetes. J Clin Invest 55:1326-1336

3. Hallman M 1984 Effect of extracellular myoinositol on surfactant phospholipid synthesis in the fetal rabbit lung. Biochim Biophys Acta 795:67-78

4. Hallman M, Epstein BL 1980 Role of myoinositol in the synthesis of phosphatidylglycerol and phosphatidylinositol in the lung. Biochem Biophys Res 
Commun 92:1151-1159

5. Quirk JG. Bleasdale JE 1983 MVo-Inositol homeostasis in the human fetus Obstet Gynecol 62:41-44

6. Batenburg JJ. Klazinga W. Van Golde LMG 1982 Regulation of phosphatidylglycerol and phosphatidylinositol synthesis in alveolar type II cells isolated from adult rat lung. FEBS Lett 147:171-174

7. Dawson RMC, Freinkel N 1961 The distribution of free mesoinositol in mammalian tissues. including some observations on the lactating rat. Biochem J 78:606-610

8. Bleasdalc JE, Maberry MC. Quirk JG 1981 Myo-Inositol homeostasis in foetal rabbit lung. Biochem J 206:43-52

9. Caspary WF. Crane RK 1970 Active transport of myoinositol and its relation to the sugar transport system in hamster small intestine. Biochim Biophys Acta 203:308-316

10. Greene DA. Lattimer SA 1981 Sodium and energy-dependent uptake of myoinositol by rabbit peripheral nerve. J Clin Invest 70:1009-1018

11. Hammerman MR. Sacktor B. Daughaday WH 1980 Myo-Inositol transport in renal brush border vesicles and its inhibition by D-glucose. Am J Physiol 239:F113-F120

12. Reddy VN, Varma SD. Chakrapani B 1970 Intraocular transport of myoinositol. I. Accumulation in the rabbit ciliary body. Invest Ophthalmol 9:785793

13. Molitoris BA, Karl IE Daughaday WH 1980 Concentration of myoinositol in skeletal muscle of the rat occurs without active transport. J Clin Invest 65:783-788

14. Reddy CC. Pierzchala PA. Hamilton GA 1984 Myo-inositol oxygenase from a kidncy. J Biol Chem 256:8519-8524

15. Michell RH 1975 Inositol phospholipids and cell surface receptor function. Biochim Biophys Acta 415:81

16. Sherman WR. Packman PM. Laird MH. Boshans RL 1977 Measurement of myo-inositol in single cells and defined areas of nervous system by selected ion monitoring. Anal Biochem 78:119-131

17. Monaco ME 1982 The phosphatidylinositol cycle in WRK-1 cells. Evidence for a separate hormone-sensitive phosphatidylinositol pool. J Biol Chem 257:2137

18. Bleasdale JE. Tyler NE. Bush FN. Quirk JG 1983 The influence of myoinositol on phosphatidylglycerol by rat type II pneumonocytes. Biochem J 212:811-818

19. Esko JD. Raetz CRH 1980 Mutants of chinese hamster ovary cells with altered membranc phospholipid composition of phosphatidylinositol with phosphatidylglycerol in a myo-inositol auxotroph. J Biol Chem 255:4474-4480

20. Burton LE. Wells WW 1974 Studies on the developmental pattern of the enzymes converting glucose 6-phosphate to myoinositol in the rat. Dev Biol $37: 35-42$

21. Hallman M. Saugstad OD. Porreco RR. Epstein BL, Gluck L 1985 Role of myoinositol in regulation of surfactant phospholipids in the newborn. Early Hum Dev 10:245-255

22. Nixon DA 1968 The concentration of free myo-inositol in the plasma of perfused sheep fetuses. Biol Neonate 12:113-120

23. Hallman M. Gluck L 1980 Formation of acidic phospholipids in rabbit lung during perinatal development. Pediatr Res 14:1250-1259

24. Gross I, Wilson CM. Ingleson LD, Brehier A, Rooney SA 1980 Fetal lung in organ culture. III. Comparison of dexamethasone, thyroxine, and methylxanthines. J Appl Physiol 48:872-877

25. Mason RJ, Nellenbogen J. Clements JA 1976 Isolation of disaturated phosphatidylcholine with osmium tetroxide. J Lipid Res 17:281-284

26. Hallman M, Epstein BL Gluck L 1981 Analysis of labcling and clearance of lung surfactant phospholipids in rabbit. Evidence of bidirectional surfactant flux between lamellar bodies and alveolar lavage. J Clin Invest 68:742-751

27. Mason RJ, Williams MC, Greenleaf RD, Clements JA 1977 Isolation and properties of type II alveolar cells from rat lung. Am Rev Respir Dis 115:1015-1026

28. Dobbs LG, Mason RJ 1979 Pulmonary alveolar type Il cells isolated from rats. Release of phosphatidylcholine in response to $\beta$-adrenergic stimulation. . Clin Invest 63:378-387

29. Phillips HJ 1973 Dye exclusion tests for cell viability. In: Kruse PF Jr, Patterson MK Jr (eds). Tissue Culture. Methods and Applications. Academic Press, Inc, New York. pp 406-408

30. Post M, Batenburg JJ, Van Golde LMG 1980 Effects if cortisol and thyroxine on phosphatidylcholine and phosphatidylglycerol synthesis by adult rat lung alveolar type II cells in primary culture. Biochim Biophys Acta 618:308-317

31. Rooney S, Gobran L Marino P Maniscalco W Gross I 1979 Effects of betamethasone on phospholipid content, composition and biosynthesis in the fetal rabbit lung. Biochin Biophys Acta 572:64-76

32. Spector R, Lorenzo AV 1975 The origin of myoinositol in brain, cercbrospinal fluid, and choroid plexus. J Neurochem 25:353-354

33. Blcasdale JE, Johnston JM 1982 CMP-dependent incorporation of ${ }^{14} \mathrm{C}$ glycerol 3-phosphate into phosphatidylglycerol and phosphatidylglycerol phosphate by rabbit lung microsomes. Biochim Biophys Acta 710:377-390

34. Quirk JC, Bleasdale JE, MacDonald PC, Johnston JM 1980 A role for cytidine monophosphate in the regulation of the glycerophospholipid composition of surfactant in developing lung. Biochem Biophys Res Commun 95:985-992

35. Cunha TJ. Inositols: Deficiency effects in animals. 1971. In: Sebrell WH, Harris RS (eds) The Vitamins: Chemistry, Physiology, Pathology, Vol 3. Academic Press, New York, pp 394-398

36. Eisenberg F Jr 1967 D-mvo-inositol I-phosphate as product of cyclization of glucose 6-phosphate and substrate for a specific phosphatase in rat tests. J Biol Chem 242:1375-1382

37. Chu S-W, Hegstedt DM 1980 Myoinositol deficiency in gerbils: changes in phospholipid composition in intestinal microsomes. J Nutr 110:1217-1223

38. Burton L, Wells WW 1979 Myo-inositol deficiency: studies on the mechanism of lactation-dependent fatty liver formation in the rat. J Nutr 109:1483-1491

39. Eagle H, Oyma VI, Levy M. Freeman AE 1957 Myo-inositol as an essential growth factor for normal and malignant cells in tissue culture. J Biol Chem 226:191-205 